\title{
Biology, fishery and trade of sea moths (Pisces: Pegasidae) in the central Philippines
}

\author{
Marivic G. Pajaro, Jessica J. Meeuwig, Brian G. Giles and Amanda C.J. Vincent
}

\begin{abstract}
Sea moths (family Pegasidae) are littlestudied benthic fish, found throughout the Indo-Pacific. Two species of sea moths, Pegasus volitans and Eurypegasus draconis, are caught incidentally in illegal trawl gear in the Philippines and sold into the dried fish trade. Approximately 130,000-620,000 P. volitans and 130,000 E. draconis were landed off north-western Bohol alone in 1996. An additional 43,000-62,000 sea moths (predominantly $P$. volitans) were caught live for the aquarium trade. Catch per unit effort for $P$. volitans was double that of E. draconis, probably because of its occurrence in shallower waters where fishing effort was
\end{abstract}

concentrated. Sea moths may be unsuited for heavy exploitation as they occur at low densities. Moreover, a female-biased catch could lower the effective population size, given the reported monogamy amongst sea moths. No population data were available for a complete conservation assessment, although divers surveyed did report declines in their abundance.

Keywords Aquarium trade, bycatch, Eurypegasus draconis, Pegasidae, Pegasus volitans, Philippines, sea moths, traditional medicine.

\section{Introduction}

Despite the recognition that most of the world's fisheries are fully or overexploited (FAO, 2000) relatively little attention has been paid to fisheries for non-food consumption. The impacts of the demand for marine animals for traditional medicines and tonic foods, ornamental display, bait, curiosities, cosmetics, chemicals, leather, and other uses are not well known. However, overexploitation of fishes for non-food use is now causing concern, particularly for some of the species used as traditional medicines (Vincent, 1996, 1997), aquarium fishes (Wood, 1992, 2001; Sadovy \& Vincent, 2002) and baits (Blaber et al., 1994).

Sea moths (family Pegasidae) comprise a poorly understood taxon of fishes that is commercially exploited for traditional medicines and aquarium display (Vincent, 1997). Inhabitants of temperate and tropical coastal zones throughout the Indo-Pacific (Palsson \& Pietsch, 1989), sea moths may be the primitive sister group of the

Marivic G. Pajaro ${ }^{1}$ (Corresponding author) Project Seahorse-Haribon Foundation for the Conservation of Natural Resources, Cebu, Philippines. E-mailm.pajaro@fisheries.ubc.ca

Jessica J. Meeuwig, Brian G. Giles ${ }^{1}$ and Amanda Vincent ${ }^{1}$ Project Seahorse, Department of Biology, McGill University,1205 Ave. Dr. Penfield, Montréal, Québec H3A 1B1, Canada.

${ }^{1}$ Present address: Project Seahorse, Fisheries Centre, The University of British Columbia, 2204 Main Mall, Vancouver, BC V6T 1Z4, Canada.

Received 28 October 2002. Revision requested 14 October 2003. Accepted 19 January 2004 seahorses, pipefishes and seadragons (family Syngnathidae) and of the ghost pipefishes (family Solenostomidae) (Pietsch, 1978). In a taxonomic revision, Palsson \& Pietsch (1989) described five species in two genera: Pegasus laternarius, P. volitans, P. lancifer, Eurypegasus draconis and E. papilio. The few studies on sea moth ecology and behaviour have suggested that sea moths possess some characteristics commonly associated with species unsuited to heavy exploitation, i.e. low population densities and established long-term pair bonds of one male and one female that mate repeatedly (Pegasus lancifer, Kuiter, 1985; Eurypegasus draconis, Herold \& Clark, 1993). Both taxa are categorized as Data Deficient on the 2003 IUCN Red list (IUCN, 2003).

Millions of sea moths are sold for traditional medicine each year in China and Hong Kong alone, with supplies coming from China, Vietnam and other areas in South-east Asia (Vincent, 1997). Dried sea moths are used primarily as treatment for respiratory ailments, in particular childhood bronchial infections, and are also thought to cure lymph node and thyroid disorders, breast cancer, goitres and diarrhoea following measles (Vincent, 1997). Live sea moths are sold for ornamental display but volumes are uncertain; the Global Marine Aquarium Database records limited imports to the United Kingdom and the USA (UNEP-WCMC, 2002) but sea moths do not appear in a comprehensive list of aquarium fish species being traded around the world (Wood, 2001). Their use in aquaria is probably limited, with interest mainly because of the oddity of their shape rather than any attractive colouration or ornamentation. 
The Philippines is among the countries catching and potentially exporting sea moths (Vincent, 1997). Two species, $P$. volitans and E. draconis, have been reported from the Philippines (Palsson \& Pietsch, 1989), and $P$. volitans was documented in trawl bycatch in the Visayan area of the central Philippines (Ordonez, 1981). A limited trade survey in 1995 reported only that an exporter in Cebu abandoned plans to export sea moths because of the low prices obtained for P. volitans in traditional medicine (Vincent, 1997).

Pegasus volitans is a slender, swift-swimming sea moth, reported to reach a maximum length of $180 \mathrm{~mm}$ (Palsson \& Pietsch, 1989). Inhabitants of muddy and sandy bottoms, they are often found in association with prawns (Conlu, 1986). They typically live at 2-30 m depth, but have also been found on the surface and as deep as $73 \mathrm{~m}$ (Palsson \& Pietsch, 1989).

Eurypegasus draconis is a wider-bodied, shorter species, with a maximum recorded length of $77 \mathrm{~mm}$ (Palsson \& Pietsch, 1989). These fish have been collected at depths as shallow as $3 \mathrm{~m}$, but are more commonly found in deeper water (37-91 m) (Palsson \& Pietsch, 1989; Herold \& Clark, 1993). E. draconis generally inhabits coarser sediment areas (sand, gravel and shell-rubble) (Palsson \& Pietsch, 1989), where they conceal themselves by mimicking a piece of broken shell (Kuiter, 1985). These fish may also occur among seagrass or patches of corals (Palsson \& Pietsch, 1989; Herold \& Clark, 1993).

Here we report on the distribution and biology of these two species of sea moth in the Philippines and use data obtained from direct monitoring and trade surveys to detail and estimate sea moth bycatch in small-scale fisheries. We also present information on the trade of sea moths and the economic importance of this trade.

\section{Methods}

\section{Bycatch monitoring}

We monitored sea moth bycatch in trawl fisheries at two sites in Bohol province, along the Danajon Bank, Banacon village (Getafe municipality) and Malinguin village (Bien Unido municipality) (Fig. 1). Bohol is located in the central Visayas region of the Philippines which, along with the adjacent Panay Islands, once accounted for 50\% of all commercial fish caught in the Philippines (Smith et al., 1980). The fishers we monitored employed two types of illegal small-mesh nets: otter trawl (palakaya) and modified Danish seine gear (liba liba) (for gear descriptions, see BFAR, 1988).

Samples of P. volitans were obtained from May 1996 to January 1997 from a small-scale grouper farmer on nearby Jandayan Island, who purchased all daily bycatch from one Banacon otter trawler to use as feed. Samples of E. draconis were obtained from a fisher using Danish seine gear in Malinguin, who set aside daily sea moth bycatch, from November 1995 to March 1996. While he sometimes caught both species, only E. draconis were kept. Specimens were placed into labelled individual plastic bags and preserved with $10 \%$ formalin.

Standard length $(\mathrm{mm})$ and weight $(\mathrm{g})$ were taken from fresh $P$. volitans specimens, while E. draconis specimens preserved in $10 \%$ formalin were measured but not

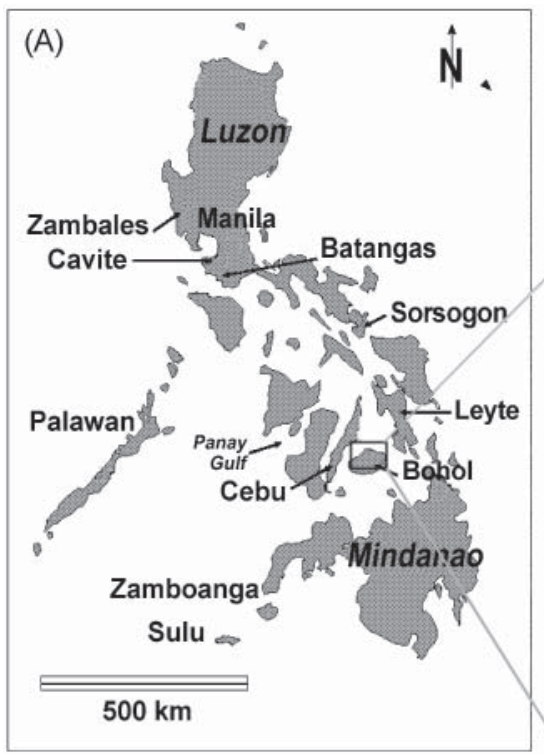

(B)

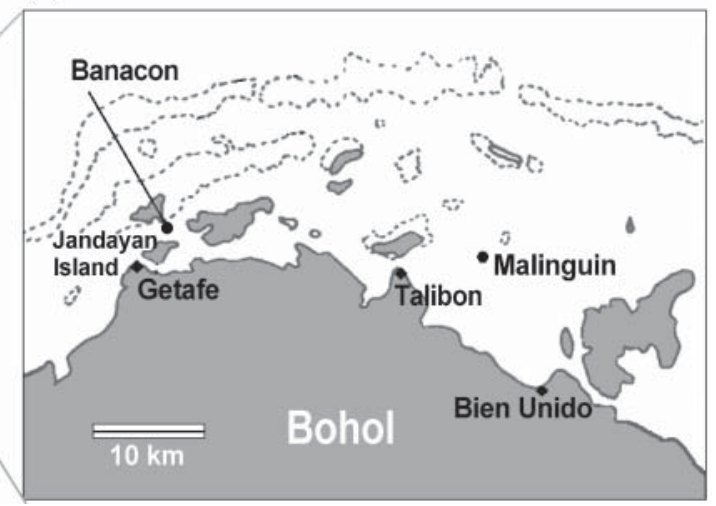

Fig. 1 (A) Map of the Philippines and (B) the Danajon Bank (Northern Bohol) showing trade survey areas and study locations. 
weighed. Preserved specimens of both species with intact internal organs were later sexed by gonad dissection. Some specimens, not preserved immediately after capture, were impossible to sex because of tissue damage.

\section{Trade studies}

We conducted trade studies focusing on two markets: dried sea moths destined for use as traditional medicines and live sea moths collected as aquarium fishes. Casual and semi-structured interviews were conducted with fishers and trade participants $(n=39)$ around the Philippines in 1995 and 1996. In the absence of an accurate list of fishers or buyers, survey participants were located through 'snowball sampling', in which initial participants referred us to additional, appropriate persons (Neis et al., 1999). In all discussions we asked about species caught, geographic distribution, catch and effort, seasonality, sources, supply and trade routes, and selling and buying prices. In addition, we asked the compressor divers about sea moth biology and the characteristics of sea moth fishing grounds. All prices are given in Philippine Pesos (PhP) and US \$, at the 1996 exchange rate of $\mathrm{PhP} 36=\mathrm{US} \$ 1$.

For the dried trade we surveyed 22 fishers, six primary buyers located on Bohol and one employee at an export facility in Cebu. Fishers from Bohol employed otter trawls $(n=4)$, Danish seines $(n=3)$ or beach seines $(\mathrm{n}=8)$. Fishers from Leyte using otter trawls $(\mathrm{n}=2)$ and beach seines $(n=4)$ were also surveyed, as was an otter trawl fisher from Palawan. For the live trade surveys we questioned seven compressor divers around Luzon (four sea moth collectors and three targeting seahorses and food fish), one primary buyer at Cavite, and an employee at each of two different aquarium export facilities in Manila.

\section{Statistical analyses}

Chi-square goodness of fit analyses with Yates correction (Zar, 1996) was used to test for departures in the sex ratio from 1:1 in bycatch, for all specimens and by size class. Differences in weight and standard length $\left(\log _{10}\right.$ transformed) between males and females within a species were tested using the $t$-test for independent means.

Total bycatch for Bohol was calculated using estimates of catch per unit effort (CPUE, fisher ${ }^{-1}$ day $^{-1}$ ) from both bycatch monitoring and trade surveys for comparison, using an estimate of fishing effort from surveys. Fishing effort could only be quantified per 24-hour period, as this was the lowest resolution at which the catch was recorded. The number of sea moths caught was converted to biomass ( $\mathrm{kg}$ wet weight) employing the average weight of $P$. volitans from catch monitoring. Total live catch was estimated by extrapolating the reported volumes purchased by an exporter in Manila to all known exporters, accounting for the primary buyerreported percent mortality between catch and sale to exporters.

\section{Results}

\section{Distribution and habitat}

Surveys suggested that both species of sea moths are found throughout the Philippines (Fig. 1). Fisher reports, supplemented with museum specimens (Palsson \& Pietsch, 1989), reported both species in Batangas, Bohol, Cavite, Leyte, Palawan, Sorsogon, Sulu and Zambales provinces (Fig. 1). P. volitans was also reported from Cebu, while E. draconis were reportedly landed as bycatch in the Panay Gulf (Fig. 1). Four compressor divers targeting sea moths in Cavite province reported finding them singly or in groups of 2-3, primarily on sandy-muddy and coralline-sandy substrates, and seldom in soft mud or heavily silted waters. Reportedly, $P$. volitans were active during the day and more easily caught when resting at night.

\section{Bycatch monitoring}

The daily bycatch of $P$. volitans was low, although it varied significantly from day to day. Total bycatch in the otter trawl was 323 fish over 42 nights sampled, with landings of 1-30 sea moths day ${ }^{-1}$ and a mean CPUE $( \pm \mathrm{SD})$ of $8 \pm 6$ fisher $^{-1}$ day $^{-1}$. Total catch was significantly female-biased, with only $36 \%$ males (83 males, 150 females) $\left(\chi^{2}=18.8, \mathrm{P}<0.001\right)$. The proportion of males decreased with increasing size: males constituted $53 \%$ of the population in the $60.0-69.9 \mathrm{~mm}$ class (37 males, 32 females), $33 \%$ in the $70.0-79.9 \mathrm{~mm}$ (41 males, 84 females), and $7 \%$ in the $80-89.9 \mathrm{~mm}$ ( 2 males, 28 females) class. When the size classes were examined individually, the sex ratio in the smallest size class did not differ from 1:1 $\left(\chi^{2}=0.232 ; \mathrm{P}=0.63\right)$, but was significantly female biased in the two larger size classes $\left(70.0-79.9 \mathrm{~mm}: \chi^{2}=14.1\right.$; $\mathrm{P}<0.001 ; 80.0$ to $\left.89.9 \mathrm{~mm}: \chi^{2}=20.8 ; \mathrm{P}<0.001\right)$.

Total bycatch of E. draconis in a Danish seine was 55 fish over 14 nights sampled, with landings of 1-17 day ${ }^{-1}$ and a mean $( \pm S D)$ CPUE of $4 \pm 4$ fisher $^{-1}$ day $^{-1}$. No E. draconis were caught by the otter trawl fisher. For the E. draconis that we could sex, the ratio of males $(\mathrm{n}=19)$ to females $(\mathrm{n}=24)$ was not significantly different from $1.0\left(\chi^{2}=0.58 ; \mathrm{P}=0.45\right)$. The small sample size prevented analysis by size class.

Mean standard length $( \pm \mathrm{SD})$ of all $P$. volitans in bycatch was $72.0 \pm 6.7 \mathrm{~mm}(\mathrm{n}=323)$ and mean weight $( \pm \mathrm{SD})$ was $2.2 \pm 0.7 \mathrm{~g}(\mathrm{n}=159)$. E. draconis $(\mathrm{n}=55)$ in 
bycatch were shorter (mean $\pm \mathrm{SD}=55.0 \pm 5.9 \mathrm{~mm}$ ), although they were measured after being preserved in formalin. For $P$. volitans that were sexed, females were significantly longer $(t=7.72 ; \mathrm{P}<0.001)$ and heavier $(t=5.17 ; \mathrm{P}<0.001)$ than males. Female E. draconis in the catch were significantly longer than males $(t=3.05$; $\mathrm{P}=0.004)$.

\section{Dried trade description and estimates}

Sea moths destined for the dried fish trade were caught incidentally in otter trawls and modified Danish and beach seines, primarily in the Visayas (Bohol, Cebu and Leyte provinces), with some probably caught in Mindanao (Jolo and Zamboanga provinces) and Palawan (Fig. 1). Sea moth bycatch was sold to primary buyers, who in turn sold them to exporters of dried marine products.

Otter trawls along the Danajon Bank were towed from small, motorized outrigger boats (4-6 m long) in sandy/ muddy areas, targeting shrimp, squid and schooling fish. Their main fishing grounds were $2-3 \mathrm{~km}$ from shore, in waters 10-20 m deep. Modified Danish seine gear was towed from similar small motorized outrigger boats. They typically fished the water adjacent to coral reefs in waters $15-30 \mathrm{~m}$ deep. Beach seine fishers on Bohol mainly targeted shrimp and anchovies in shallow seagrass beds and muddy water.

Most of the sea moths caught in otter trawls were $P$. volitans; one fisher remembered catching only one E. draconis in the previous 6 months. Danish seines also caught more $P$. volitans than E. draconis, except in the fishing grounds near Leyte. Both species were rarely caught in the same haul. Only one of eight beach seine fishers in Bohol recalled ever catching sea moths, although three fishers from Leyte reported catching low numbers of E. draconis, which they discarded. Buyers in Bohol reported obtaining many more $P$. volitans than E. draconis, and presumably mixed the two species before selling them on to exporters.

Otter trawl fishers from Bohol reported peaks in sea moth ( $P$. volitans) catch at $20-30$ day $^{-1}$ coinciding with peaks in catch of their targeted species (squids or shrimps) in December-May. This estimate was more than three times greater than our observed CPUE of 8 day $^{-1}$ based on a sampling period (May-January) that did not include all of the fishers' reported peak months. Fishers using modified Danish seine nets estimated their P. volitans catch to be $0-10$ day $^{-1}$, but we lack CPUE data to support this claim.

All six primary buyers interviewed were aware of a trade in sea moths, but only three purchased them (mainly P. volitans) from fishers. Two of the buyers' estimates of sea moth purchases were $0.08 \mathrm{~kg}_{\text {fisher }}^{-1}$ month ${ }^{-1}$ and $0.25-0.38 \mathrm{~kg}_{\text {fisher }}^{-1}$ month $^{-1}$. Based on the average estimate of 650 sea moths per $\mathrm{kg}$ reported by buyers (from a reported range of 600-700), such purchases would equate to a range of 52-247 sea moths fisher $^{-1}$ month $^{-1}$ or 3-16 sea moths fisher ${ }^{-1}$ day $^{-1}$ given that they fish 15 days per month. A third buyer reported receiving $1 \mathrm{~kg}$ per day from 10 fishers (representing 10 boats). However, this would require a daily catch rate (65 sea moths fisher ${ }^{-1}$ day $^{-1}$ ), more than twice the maximum reported by fishers, and was therefore not included in our estimate of total catch.

According to interviews with fishers and traders, c. 208 otter trawlers along Danajon Bank fished for an average of 5 days per week for about 3 weeks each month throughout the year. From this data we estimated total annual $P$. volitans landings of 300,000 (660 kg wet weight) based on the average CPUE from monitoring (Table 1). One hundred and fifteen modified Danish seine boats fishing an average of 6 days per week would have landed an estimated 130,000 E. draconis (286 kg wet weight) annually (Table 1$)$. These estimated annual catch totals were within the range of estimates (130,000-620,000 sea moths; 286-1364 kg wet weight), obtained using buyers' estimates of trade volumes (Table 1). Buyer records represent a minimum sea moth catch, as they did not include any discarded catch.

\section{Aquarium trade surveys}

Sea moths destined for the live trade were targeted and caught by compressor divers in Luzon (Batangas, Cavite, and Zambales provinces) (Fig. 1) and sold to primary buyers who reportedly sold them to ornamental fish exporters in Manila who then shipped them to Japan, Europe and North America. Compressor divers targeted both species, although $P$. volitans were taken more commonly, reportedly because $E$. draconis lived in deeper water, making them relatively inaccessible and unlikely to survive the decompression to the surface. Divers in Cavite noted that they caught more $P$. volitans after the south-west monsoon (May-October), when the water became calmer, but did not comment on any change in effort at that time.

A Manila-based exporter with a medium-sized facility (c. $25 \mathrm{~m}^{2}$ storage space) reported receiving 1,100-1,700 sea moths per annum from 2-3 buyers. If his total receipts were representative, then the 30 aquarium fish exporters in Manila in 1995 would have received c. 33,000-51,000 sea moths per annum from buyers around the Philippines. A primary buyer from Cavite reported about $20 \%$ mortality in his facility before shipping to exporters. If this is representative of mortality experienced by other primary buyers, the total number caught by fishers and sold to buyers would have been 
Table 1 Estimates of total annual catch from the Danajon bank region, Central Philippines, of (a) P. volitans and (b) E. draconis (with 95\% confidence intervals) based on average estimates of catch per unit effort from bycatch monitoring, and (c) all sea moths based on reported numbers supplied to primary buyers.

\begin{tabular}{lcc}
\hline Source of estimate & Catch fisher ${ }^{-1}$ month $^{-1}$ & Total annual catch \\
\hline a) $P$. volitans $^{1}$ (bycatch monitoring, Banacon) & $120(90-150)$ & $299,520(224,640-374,440)$ \\
b) E. draconis ${ }^{2}$ (bycatch monitoring, Malinguin) & $96(48-144)$ & $132,480(66,240-198,720)$ \\
c) All sea moths & 54 & 134,784 \\
Buyers, Banacon: minimum & 247 & 616,512 \\
Buyers, Banacon: maximum & & \\
\hline
\end{tabular}

${ }^{1}$ Total catch was extrapolated from monthly catch per fisher $\times 208$ fishers $\times 12$ months; monthly catch was calculated as $8(95 \% \mathrm{CI}=6-10)$ day $^{-1} \times 15$ days.

${ }^{2}$ Total catch was extrapolated from monthly catch per fisher $\times 115$ fishers $\times 12$ months; monthly catch was calculated as $4(95 \% \mathrm{CI}=2-6)$ day $^{-1} \times 24$ days.

41,000-64,000 sea moths. The exporter acknowledged that $25 \%$ of the sea moths he received from the buyer died in his facility.

\section{Economic value}

Fishers earned little income from selling sea moths. Buyers of dried fish around Bohol reported paying PhP 0.25-0.50 (<US \$0.01) per dead sea moth (PhP 150-350 or US \$4.16-9.72 per dried $\mathrm{kg}$ ). Even at the maximum reported catch of 30 per day, this would provide at most PhP 15 per day, approximately $6-20 \%$ of fishers' reported daily income of PhP 75-250 (US \$2.78-6.94).

Buyers considered pegasids to be relatively minor contributors to their income, despite selling the dried sea moths to exporters at PhP 300-500 per kg (US \$8.3513.90), nearly double what they paid fishers. One buyer, who mainly traded other fishery products (sea cucumber, fresh fish, and seahorses), reportedly earned only $5 \%$ of total income from sea moths.

Sea moths were worth more alive than dead, both to the fisher and the buyer. Fishers received $\mathrm{PhP} 3-4$ (US \$0.08-0.11) for each live sea moth destined for the aquarium trade. The buyer in Cavite sold the live sea moths to a large volume exporter, purportedly at PhP 610 (US \$0.17-0.28) per sea moth. The exporter indicated that he paid PhP 10 per sea moth, before selling them to Japan and the United States at undisclosed prices. Money from live sea moths was reportedly important to divers and the primary buyer as supplementary income for rice and other food, although fishers earned more from the food fishes they speared during the night, and buyers earned more from other aquarium products such as cowfishes and sea anemones.

\section{Discussion}

This is the first analysis of a sea moth fishery. Both Pegasus volitans and Eurypegasus draconis were taken in non-selective fishing gear, in cumulatively sufficient numbers to support a dried traditional medicine trade. Smaller numbers were also directly targeted and exported live for the aquarium trade. P. volitans was more commonly caught and traded, presumably because it inhabited shallower water where fishing activity was highest. Sea moths were not an economically significant trade, although their importance may increase as other species decline. We lack the required fisheries and population data to make a detailed assessment of the conservation status of this species. However, their life history characteristics (low densities, monogamy and possibly biased sex ratios) may make them unsuitable for heavy exploitation.

Despite relatively low daily catch rates, sea moth populations may be under pressure from non-selective fishing gear; illegal trawlers landed 130,000-620,000 sea moths, primarily $P$. volitans, in north-west Bohol alone. This type of illegal trawling continues today, although reportedly at a lower level because of better enforcement. These bycatch numbers do not include any $P$. volitans caught in Danish seines or E. draconis in the numerous beach seines widely employed around Bohol. As a comparison, catch surveys estimated that 800,000 seahorses (Hippocampus spp.) were caught incidentally each year in the Philippines based on similar levels of bycatch (reported range 1-20 day ${ }^{-1}$ fisher $^{-1}$ ) and $>2$ million seahorses were caught annually in Vietnam, despite daily catches in trawls of only 1-2 individuals (A. Vincent, unpubl. data). Fishers in both areas reported declines from historical catch levels (A. Vincent, unpubl. data).

Fishers supplying the Manila aquarium export market might have caught an additional 41,000-64,000 sea moths per year. Sea moths constitute only a fraction of the total aquarium fish exports from the Philippines, estimated at 6 million fish in 1996 (Wood, 2001). Sea moths appear unsuitable as aquarium species because of the high rate of mortality post-catch, reportedly $40 \%$, which is higher 
than the average of $8-10 \%$ reported for most aquarium species (Wood, 2001).

$P$. volitans was caught more often than E. draconis, with a catch per unit effort in Bohol of almost twice, although estimates came from different trawl gear in areas $40 \mathrm{~km}$ apart. The difference in catch rates could be related to the different habitat preferences of the two species, as they were rarely caught simultaneously. The more frequently caught $P$. volitans were mainly found in shallower waters (Palsson \& Pietsch, 1989) where fishing activity was highest. Otter trawls were reportedly used in shallower water $(10-20 \mathrm{~m})$ rather than Danish seines (15-30 m), which accounts for the apparent lack of E. draconis bycatch in the former. Trawlers normally target shallower water even though the Philippines forbids trawling within $15 \mathrm{~km}$ of the coast; such illegal fishing is rampant. Both gears employed similar mesh sizes $(<3 \mathrm{~cm})$. However, whether the difference in catches reflected differences in habitat, as opposed to differences in abundance, fishing methods or location, or susceptibility to fishing, cannot be determined from the available information.

There was little targeted fishing for sea moths, and no fisher or buyer reported dependency on income from sea moths, regarding them instead as useful extra money. Sea moths were worth far more to fishers and buyers live than dried, but most fishers had little choice as they could only access one market for sea moths, either live or dried. This problem of limited choice of markets often restricts fishers' opportunities (Smith et al., 1980). However, declines in other economically important target species, including seahorses, could result in more fishers collecting sea moths to supplement their income (Vincent, 1997). Trade studies from the mid-1990s suggested that millions of pegasids ( $P$. volitans and P. laternarius) were sold annually in China and Hong Kong, despite relatively low demand, with most coming from China and Vietnam (Vincent, 1997). However, this earlier study did not document a consistent trade in the Philippines in 1995. In 2003, local residents reported that the dried trade in northern Bohol had ceased because of lack of demand, though the live trade in other parts of the country continues (M. Pajaro, pers. obs.) .

We cannot determine the impact of harvesting on sea moth populations without independent population estimates. Compressor divers in Cavite in the northern Philippines commented that sea moth catches had decreased considerably and attributed this decline to non-targeted overexploitation by trawlers, along with active dredging on their fishing grounds. Similar population declines in seahorses have been reported and attributed to bycatch, direct exploitation and habitat degradation (Vincent, 1996). While the wide geographic distribution of pegasid species could buffer them against localized habitat loss or exploitation, certain life history characteristics may make them unsuitable for heavy exploitation (Vincent, 1997). Direct observations and data from fisheries bycatch indicate that both species exist at relatively low densities. Herold \& Clark (1993) suggested that overexploitation of sea moth populations might result in reduced reproductive success, as their low mobility and densities makes finding a partner difficult. This concern may be increased by the apparent female bias in catch, especially at larger sizes. If $P$. volitans are monogamous, like E. draconis (Herold \& Clark, 1993), then removing disproportionate numbers of females will leave males without mates, and unable to breed. A review of species taken as bycatch in the Australian prawn fishery ranked E. draconis as having higher than average susceptibility to capture by trawls (Stobutzki et al., 2001).

The sea moth trade in the Philippines is an example of a previously undocumented fishery for non-food consumption. Despite their widespread occurrence, little was known of the economic importance or ecological effects of these fisheries, which supply traditional medicine, aquaria, curio, bait and other non-food uses. These fisheries are rarely regulated or documented and even basic trade data are commonly unavailable. Although small in scale, these fisheries are potentially necessary sources of income for subsistence fishers in developing nations. More documentation and study is required to assess the sustainability and possible importance of these non-traditional fisheries and to determine the conservation status of the species involved.

\section{Acknowledgements}

This is a contribution from Project Seahorse. We are grateful to the fishers who helped with specimen collection, and to the fishers, buyers, and aquarium facility technicians who kindly granted interviews. We sincerely thank Dale Marsden for his assistance in the completion of this manuscript, and Keith Martin-Smith and Sian Morgan for reading the manuscript critically. This work was funded by a grant from Fauna \& Flora International's 100\% Fund, for which we are most grateful. J. Meeuwig and B. Giles were supported by Guylian Chocolates Belgium, while A. Vincent's costs were covered by the Project Seahorse/John G. Shedd Aquarium partnership for marine conservation.

\section{References}

BFAR (1988) A Handbook on Selected Philippine Fishing Gears and Methods. Bureau of Fisheries and Aquatic Resources, Manila, Philippines. 
Blaber, S.J.M., Milton, D.A., Ralinson, N.J.F. \& Sesewa, A. (1994) Predators of tuna baitfish and the effects of baitfishing on the subsistence reef fisheries of Fiji. Tuna Baitfish in Fiji and Solomon Islands, 52, 51-61.

Conlu, P.V. (1986) Fishes: Guide to the Philippine Flora and Fauna, Vol. 9. Ministry of Natural Resources and University of the Philippines, Manila, Philippines.

FAO (Food and Agriculture Organization) (2000) The State of World Fisheries and Aquaculture. Food and Agriculture Organization, Rome, Italy.

Herold, D. \& Clark, E. (1993) Monogamy, spawning and skin-shedding of the sea moth, Eurypegasus draconis (Pisces: Pegasidae). Environmental Biology of Fishes, 37, 219-236.

IUCN (2003) 2003 IUCN Red List of Threatened Species. IUCN, Gland, Switzerland [http:/ / www.redlist.org, accessed 2 December 2003].

Kuiter, R. (1985) The remarkable sea moths. Scuba Diver, 3, 16-18.

Neis, B., Schneider, D.C., Felt, L., Haedrich R.L., Fischer, J. \& Hutchings, J.A. (1999) Fisheries assessment: what can be learned from interviewing resource users? Canadian Journal of Fisheries and Aquatic Science, 56, 1949-1963.

Ordonez, J. (1981) Study of the trash fish caught by otter trawl in the Visayan sea. MSc thesis, University of the Philippines in Diliman, Philippines.

Palsson, W.A. \& Pietsch, T.W. (1989) Revision of the acanthopterygian fish, family Pegasidae (order Gasterosteiformes). Indo-Pacific Fishes, 18, 1-38.

Pietsch, T.W. (1978) Evolutionary relationships of the sea moths (Teleostei: Pegasidae) with a classification of gasterosteiform families. Copeia, 3, 517-529.

Sadovy, Y.J. \& Vincent, A.C.J. (2002) Ecological issues and the trades in live reef fishes. In Coral Reef Fishes: Dynamics and Diversity in a Complex Ecosystem (ed. P.F. Sale), pp. 391-420. Academic Press, San Diego, USA.

Smith, I.R., Puzon, M.Y. \& Vidal-Libunao, C.N. (1980) Philippines municipal fisheries: a review of resources, technology and socio-economics. ICLARM Studies and Reviews 4. International Center for Living Aquatic Resources Management, Manila, and the Fishery Industry Development Council, Manila, Philippines.
Stobutzki, I., Miller, M. \& Brewer, D. (2001) Sustainability of fishery bycatch: a process for assessing highly diverse and numerous bycatch. Environmental Conservation, 28, 167-181.

UNEP-WCMC (2002) Global Marine Aquarium Database.

UNEP-WCMC, Cambridge, UK. [http://www.

unep-wcmc.org/marine/GMAD/index.html, accessed 2 December 2003]

Vincent, A.C.J. (1996) The International Trade in Seahorses. TRAFFIC International, Cambridge, UK.

Vincent, A.C.J. (1997) Trade in pegasid fishes (sea moths), primarily for traditional Chinese medicine. Oryx, 31, 199-208.

Wood, E.M. (1992) Trade in Tropical Marine Fish and Invertebrates for Aquaria: Proposed Guidelines and Labelling Scheme. Marine Conservation Society, Ross-on-Wye, UK

Wood, E.M. (2001) Collection of Coral Reef Fish for Aquaria: Global Trade, Conservation Issues and Management Strategies. Marine Conservation Society, Ross-on-Wye, UK.

Zar, J.H. (1996) Biostatistical Analysis, 3rd edition. Prentice Hall, New Jersey, USA.

\section{Biographical sketches}

Marivic Pajaro was national coordinator of Project SeahorsePhilippines until 2001 and is now studying the effectiveness of marine protected areas in the Philippines with Project Seahorse, an international organization working to advance marine conservation.

Dr. Jessica Meeuwig was a research scientist with Project Seahorse until 2001 and is now based in Australia.

Brian Giles is a Senior Research Assistant with Project Seahorse.

Dr. Amanda Vincent holds the Canada Research Chair in Marine Conservation and is the Co-founder and Director of Project Seahorse. 